\title{
Assessing the extent of local crust assimilation within the Flatreef, northern limb of the Bushveld Igneous Complex, using sulfur isotopes and trace element geochemistry
}

\author{
Evan Keir-Sage $^{1} \cdot$ Matthew I. Leybourne ${ }^{2,3}$ (D) $\cdot$ Pedro J. Jugo ${ }^{1}$ - Danie F. Grobler ${ }^{4}$. Cédric C. Mayer ${ }^{1}$
}

Received: 14 April 2020 / Accepted: 20 October 2020 / Published online: 5 November 2020

(C) The Author(s) 2020

\begin{abstract}
The proximity to metasedimentary footwall rocks relative to platinum group element (PGE) mineralized intrusive rocks in the northern limb of the Bushveld Igneous Complex (BIC) has resulted in complex local contamination in the intrusions. To assess the extent of incorporation of non-magmatic material and its effects on PGE mineralization, major element, trace element, and S isotopic data were collected from drill core UMT094 on the Turfspruit farm, where core logging has shown that the mineralized Platreef, forming the Flatreef deposit, is located stratigraphically well above local sedimentary footwall rocks. The $\mathrm{S}$ isotopic data combined with whole rock geochemistry data (including $\mathrm{CaO} / \mathrm{Al}_{2} \mathrm{O}_{3},(\mathrm{~V} / \mathrm{Ti})_{\mathrm{PM}},(\mathrm{Ni} / \mathrm{Cr})_{\mathrm{PM}}, \mathrm{S} / \mathrm{Se}$, loss on ignition) were used to assess incorporation of a range of local footwall material. The $\delta^{34} \mathrm{~S}$ data show a steady decrease from the footwall assimilation zone $\left(\delta^{34} \mathrm{~S}\right.$ typically + 8 to $+9 \%$, maximum $12 \%$ ) to near constant $\delta^{34} \mathrm{~S}$ values $\left(\delta^{34} \mathrm{~S}<+4 \%\right.$ o) below the main PGE reef. Similar values have been documented for the Merensky Reef in the eastern and western limbs of the BIC $\left(\delta^{34} \mathrm{~S} \sim 0\right.$ to $+3.5 \%$ ) . Other geochemical parameters, such as $\mathrm{S} / \mathrm{Se}$ and $\mathrm{CaO} / \mathrm{Al}_{2} \mathrm{O}_{3}$, also match the ranges documented for the Merensky Reef elsewhere in the BIC. In addition, parameters such as whole rock V/Ti, normalized to primitive mantle $(\mathrm{V} / \mathrm{Ti})_{\mathrm{PM}}$, are shown to be useful indicators of contamination and the type of contaminant with $1<(\mathrm{V} / \mathrm{Ti})_{\mathrm{PM}}<2$ for uncontaminated magmatic units; $[\mathrm{V} / \mathrm{Ti}]_{\mathrm{pm}}>2$ for shale assimilation; and $[\mathrm{V} / \mathrm{Ti}]_{\mathrm{pm}}<1$ for carbonate assimilation. The results suggest that the main PGE mineralization in the Flatreef deposit formed without significant in situ contamination and that the primary mechanism of PGE mineralization in the Platreef at Turfspruit was no different than the mechanism that generated the Merensky Reef in the eastern and western limbs of the BIC.
\end{abstract}

Editorial handling: W. D. Maier

Supplementary Information The online version contains supplementary material available at https://doi.org/10.1007/s00126-020-01024-1.

Matthew I. Leybourne

m.leybourne@queensu.ca

1 Mineral Exploration Research Centre, Harquail School of Earth Sciences, Laurentian University, Sudbury, Canada

2 Queen's Facility for Isotope Research (QFIR), Department of Geological Sciences and Geological Engineering, Queen's University, Kingston, Ontario K7L 3N6, Canada

3 Arthur B. McDonald Canadian Astroparticle Physics Research Institute, Department of Physics, Engineering Physics \& Astronomy, Queen's University, Kingston, Ontario K7L 3N6, Canada

4 Ivanplats (Pty) Ltd, Mokopane, South Africa

\section{Introduction}

The Bushveld Igneous Complex (BIC) is a layered mafic to ultramafic igneous complex located in the north-eastern part of the Republic of South Africa. It hosts the largest known accumulation of Pt-Pd mineralization in the world (Mudd 2012). The Rustenburg Layered Suite (RLS) consists of a series of mafic and ultramafic layers that can be traced throughout the BIC in the western, eastern, and part of the northern limb. Although PGE mineralization in the eastern and western limbs of the BIC is well studied and characterized, the origin of PGE mineralization in the northern limb and its correlation with the eastern and western limbs has proven difficult, mostly because well-exposed mineralization along the northern limb typically occurs in sections showing strong interaction between BIC 
magmas and country rocks (the Platreef; Gain and Mostert 1982; Kinnaird 2005; McDonald et al. 2011). PGE mineralization in the eastern and western limbs is primarily hosted within the Merensky Reef and Upper Group 2 (UG2) chromitite (Cawthorn et al. 2006), both within the Upper Critical Zone of the BIC. In contrast, PGE mineralization in the northern limb is typically in igneous sequences that are interfingered with a variety of basement lithologies including banded-iron formation, dolostone (marble), and (meta) shale (Buchanan et al. 1981; Kinnaird 2005). The stratigraphic interval showing magma-footwall interaction is up to $400 \mathrm{~m}$ in thickness and constitutes the Platreef Unit (Maier et al. 2020). Within this interval of magma-footwall interaction, particularly well-mineralized sub-units (up to about $40 \mathrm{~m}$ in thickness) occur (Grobler et al. 2019).

Much of the S-isotopic research on the Platreef (Sharman-Harris et al. 2005; Buchanan et al. 1981; Holwell et al. 2007; Yudovskaya et al. 2013; Magalhães et al. 2018; Manyeruke 2005) used samples in which magmatic units of the BIC have been variably affected by assimilation of Transvaal metasedimentary rocks. This proximal contamination has prevented a clear understanding of the relative importance of assimilation of footwall lithologies on PGE mineralization in the Platreef. The present study focuses on whole rock geochemistry and $\mathrm{S}$ isotopes $\left(\delta^{34} \mathrm{~S}\right)$ of drill core samples from the down-dip portions of the Platreef, termed Flatreef due to a change in the slope of magmatic units to sub-horizontal layering. Drill core from this area (e.g., UMT094) shows that there is a clear macroscopic separation between the economically mineralized reefs. Intervals with high PGE-Ni-Cu grades lack visible evidence of assimilation but show increasing evidence of contamination below the reefs. This study complements the work of Mayer et al. (2020, this issue), which focuses on the $\mathrm{Sr}$ isotopic stratigraphy of the transition between the Upper Critical Zone and the Main Zone in the northern limb of the BIC.

\section{Geology and stratigraphy of the Bushveld Complex}

The Bushveld Igneous Complex is subdivided into six stratigraphic zones: (1) Marginal Zone; (2) Lower Zone; (3) Lower Critical Zone; (4) Upper Critical Zone; (5) Main Zone; and (6) Upper Zone. Extensive descriptions of the BIC are well documented elsewhere (Cawthorn et al. 2006; Barnes et al. 2010; Kruger 2005; Maier et al. 2013) and will be only summarized here briefly. The Marginal Zone is the basal unit, in contact with footwall rocks, and is made up of olivine melanorite and gabbronorite, mafic sills, and variably assimilated country rocks (Engelbrecht 1990). The Lower Zone lies on top of the Marginal Zone and is comprised of harzburgite and pyroxenite, with accessory chromite and minor plagioclase as intercumulus phases (Cameron 1978). The Lower Critical Zone has a gradational basal contact and primarily comprises pyroxenite, with minor amounts of harzburgite. The Lower Critical Zone contains several laterally extensive chromitite seams. The Upper Critical Zone is made up of orthopyroxenite, norite, and anorthosite. It also hosts several chromitite layers and the bulk of the PGE resources within the BIC, within laterally extensive reefs, notably the UG2 chromitite and the Merensky Reef. The Merensky Reef is a laterally continuous cumulate layer of orthopyroxene, plagioclase, chromite, and, in places, olivine, which bears PGE and up to a few percent sulfide minerals, primarily pyrrhotite, pentlandite, and chalcopyrite. Most PGE occur within or near the Merensky Reef pegmatoid and chromite stringers (Naldrett et al. 2009). Above the Critical Zone are the Main Zone and the Upper Zone. The Main Zone is the thickest unit of the complex. It is comprised mostly of norite and gabbronorite with less abundant anorthosite and pyroxenite (e.g., Cawthorn et al. 2006; Maier et al. 2013). The Main Zone lacks significant PGE deposits and contains no chromite. Above the Main Zone lies the Upper Zone that contains more than 20 laterally continuous magnetite layers, analogous to the laterally extensive chromitite seams of the Critical Zone.

\section{The Platreef}

In the northern limb, sections of the Upper Critical Zone interfinger with various units of the Transvaal Supergroup metasedimentary rocks or rest on the Archean granite-gneisses of the Kaapvaal Craton. The Transvaal metasedimentary rocks near the Turfspruit farm include dolostone (now marble) of the Malmani Subgroup, carbonaceous (meta) shale of the Duitschland Formation, and banded iron formation of the Penge Formation. To the north, the Transvaal metasedimentary rocks pinch out between the Archean granite-gneisses and the BIC. Satellite bodies of the Lower Zone outcrop at various localities within the metasedimentary rocks and have been proposed to be associated with large scale faults (Yudovskaya et al. 2013). Substantial contact metamorphism of Transvaal rocks was documented by Armitage et al. (2002) and Eroglu et al. (2015).

The Platreef Unit is defined as a stratigraphic correlative of the Upper Critical Zone (including the Merensky Reef) in the western and eastern limbs of the Bushveld Complex (Wagner 1929; Maier et al. 
2020). The Platreef Unit contains layers of PGE mineralization that some authors interpret as correlatives of the Merensky and Bastard reefs of the western and eastern Bushveld (Grobler et al. 2019). However, the thickness of the PGE mineralization in the Platreef ( $20-90 \mathrm{~m}$ ) is much greater than the thickness of the Merensky Reef in the eastern and western limbs $(0.8$ $4 \mathrm{~m}$ ). Thus, other authors remain skeptical of such a correlation, and there is no consensus as of yet (Holwell et al. 2007; Kinnaird 2005; McDonald et al. 2011; Buchanan et al. 1981; Kruger 2005). A key difference between the Platreef in the northern limb and the Upper Critical Zone in the eastern and western limb of the BIC is the close spatial association with the footwall granite, banded iron formation, dolostone, and shale. This proximity, which resulted in intensive magma-country rock interaction, changed the appearance of the Platreef in many places so that it is commonly compositionally and lithologically distinct from the Upper Critical Zone in the eastern and western limbs (Harris and Chaumba 2001; Armitage et al. 2002). In some locations of the northern limb, the Lower Zone is located beneath the footwall units of the RLS, whereas elsewhere it is seen to have intruded into the lower portions of the critical zone (Yudovskaya et al. 2013). This is interpreted as indicating that the northern limb could have been intruded as a series of sills (Manyeruke et al. 2005), interfingering with the various footwall lithologies.

\section{Methods}

\section{Drill core and surface sampling}

Most samples were collected from drill core UMT094, located in the western portion of the project area where the Flatreef is intersected at a depth of $>1000 \mathrm{~m}$ (Maier et al. 2020). This drill core was selected because previous company logging, as well as core logging performed on site showed a clear, macroscopic separation between mineralized reef intervals and relatively contaminated footwall rocks of the reefs. Drill core samples ranged from 15 to $30 \mathrm{~cm}$ in length of NQ core, as either half-core or quarter-core sections, depending on core availability. Sampling through some of the mineralized stratigraphy was limited to whole rock pulps because the core had been extensively sampled previously. Where possible, sampling avoided granitic veins to ensure that only representative samples of the magmatic or assimilated stratigraphy were used for whole rock geochemistry. In addition to drill core samples, twelve samples, consisting mostly of Timeball
Hill shales and quartzites, and Malmani dolostone, were collected at surface from the Dehoop farm, several kilometers to the $\mathrm{E}$ of the basal contact of the Bushveld Complex, to obtain reference geochemical and isotopic values of potential assimilated sedimentary material.

\section{Petrography}

Thin sections for 36 selected samples were prepared at the Harquail School of Earth Sciences (HES). Transmitted and reflected light microscopy was used for petrographic characterization. Raman spectroscopy data was collected at Laurentian University (Canada) using a HORIBA Jobin Yvon XploRA spectrometer with an Olympus BX-41 microscope. The excitation wavelength used was $532 \mathrm{~nm}$ and an approximate beam size of $2 \mu \mathrm{m}$. Spectra were obtained over the range of 100 $1000 \mathrm{~cm}^{-1}$ using a counting time of $120 \mathrm{~s}$ and a grating of $1200 \mathrm{~cm}^{-1}$. Calibration was conducted using synthetic $\mathrm{Si}$ and the $521 \mathrm{~cm}^{-1}$ line as reference.

\section{Whole-rock geochemistry}

Samples for whole rock geochemistry were crushed and pulverized at HES with a steel hammer and a low-Cr-Mo steel disk mill. Samples were sent to at ALS Geochemistry (North Vancouver, Canada) for analysis by different methods: (1) ALS method MEMS61L: four acid digestion $\left(\mathrm{HClO}_{4}, \mathrm{HF}, \mathrm{HNO}_{3}, \mathrm{HCl}\right)$ with analysis by inductively coupled plasma optical emission spectroscopy and mass spectrometry (ICPOES and ICP-MS) for determination of trace metals and metalloids not suitable for fusion digestion; (2) ALS method ME-MS81: lithium-metaborate fusion with analysis of major elements by ICP-OES and trace elements by ICP-MS; and (3) ALS method PGMMS23L (PGM-ICP27 where over range for MS23L): ICP-MS following $\mathrm{PbO}$ fire assay for gold, platinum, and palladium contents. In addition, $\mathrm{Pt}, \mathrm{Pd}, \mathrm{Au}, \mathrm{Rh}$, $\mathrm{Ni}, \mathrm{Cu}, \mathrm{Cr}$, and $\mathrm{S}$ data were provided by Ivanplats from their $\sim 1-\mathrm{m}$ sample assaying through most of the drill core. Quality assurance and quality control data for ALS analyses are presented in Electronic Supplementary Material (ESM) Table 1.

\section{Sulfur isotopes}

Sulfur isotopic data were collected at the Queen's Facility for Isotope Research (QFIR), Queen's University (Canada). Sulfur isotope analyses were completed using both whole rock powders and by microdrilling of sulfide minerals. Sulfur isotope samples 
were weighed into tin capsules and analyzed using a Finnigan MAT 253 stable isotope ratio mass spectrometer system coupled to a Costech ECS 4010 elemental analyzer. The certified reference material (CRM) used was NBS-127 as well as two in-house barite standards from QFIR (M6801, with a $\delta^{34} \mathrm{~S}$ value of $13.6 \%$ and mrc, with a $\delta^{34} \mathrm{~S}$ value of $2.0 \%$ ). The $\delta^{34} \mathrm{~S}$ values are reported with respect to the Vienna Canyon Diablo Troilite (VCDT) standard. Values are reported using the delta $(\delta)$ notation in per mill units $(\% o)$, and sample duplicate analyses were reproducible within $0.2 \%$. For microdrilled samples, where sufficient material remained, X-ray diffraction was performed to confirm the mineralogy (sulfide versus sulfate).

\section{Results}

\section{Core logging and field relationships}

The bulk of drill core UMT094 intersected the Main Zone $(0-1200 \mathrm{~m})$. Because the focus of the study is on interaction with local country rocks, our sampling started in the Bastard Unit (BU), 1230 to $1239 \mathrm{~m}$, and includes samples from the unmineralized Middling unit (MD1; 1239 to $1252 \mathrm{~m}$ ) and the mineralized Merensky Unit (MU; 1252 to $1292 \mathrm{~m}$ ). The sampled rocks consist of cumulate pyroxene with interstitial plagioclase and minor interstitial sulfides. Petrographic examination has shown that plagioclase is commonly altered to white mica and clay minerals. The upper part of the $\mathrm{MU}$ is dominantly a medium-grained feldspathic orthopyroxenite with irregular pegmatoidal patches and is referred to as the Merensky 2 (M2). The lower part of the MU is pegmatoidal throughout and is referred to as the Merensky 1 (M1). The boundary between the M2 and $\mathrm{M} 1$ is transitional with a gradual increase in the proportion of the pegmatoidal texture. Merensky 1 is further subdivided into $\mathrm{M}_{\mathrm{U}}$ (containing little or no olivine) and $M 1_{L}$, consisting of harzburgite. Several quartz-feldspar veins (QFV) ranging between 5 and $40 \mathrm{~cm}$ in thickness sharply cut sections of the MU (three within 1228 to $1231 \mathrm{~m}$, four within 1249 to $1253 \mathrm{~m}$, one from 1270.0 to $1270.4 \mathrm{~m}$ ). Within the gabbronoritic footwall unit (FU, 1292 to $1326 \mathrm{~m}$ ), plagioclase is the dominant mineral with variable proportions of pyroxene. The unit contains small xenoliths and local bands of veining and/or increased alteration. The xenoliths are concentrated between 1294 and $1300 \mathrm{~m}$, are 10 to $30 \mathrm{~cm}$ in diameter, and are commonly of pyroxenitic composition or have been altered to serpentinite. The upper group 2 unit (UG2U) lies below the FU, beginning at $1326 \mathrm{~m}$, and is characterized by a decrease in plagioclase content $(<5$ modal \%). The upper section of the UG2U (1326 to $1347 \mathrm{~m}$ ) is similar in appearance to the $\mathrm{BU}$ and $\mathrm{MU}$, with only a relatively thin layer of pegmatoid, from 1333.3 to $1333.6 \mathrm{~m}$. Between 1333.6 and $1336 \mathrm{~m}$, there is a partially digested carbonaceous xenolith, containing serpentine, magnetite, calcite, pentlandite, pyrrhotite, minor pyrite, anhydrite, and chalcopyrite. The footwall assimilation zone (FAZ) is between 1360 and $1405 \mathrm{~m}$, containing xenoliths of up to $>1 \mathrm{~m}$ in width.

Several metamorphic minerals were identified within the calc-silicate and dolostone footwall, by use of a combination of petrography, Raman spectroscopy, and microprobe analyses. These minerals include, and are not limited to, clinohumite, Mg-Fe-Al spinel, vesuvianite, calcite (Fig. 1a), and olivine (Fig. 1b).
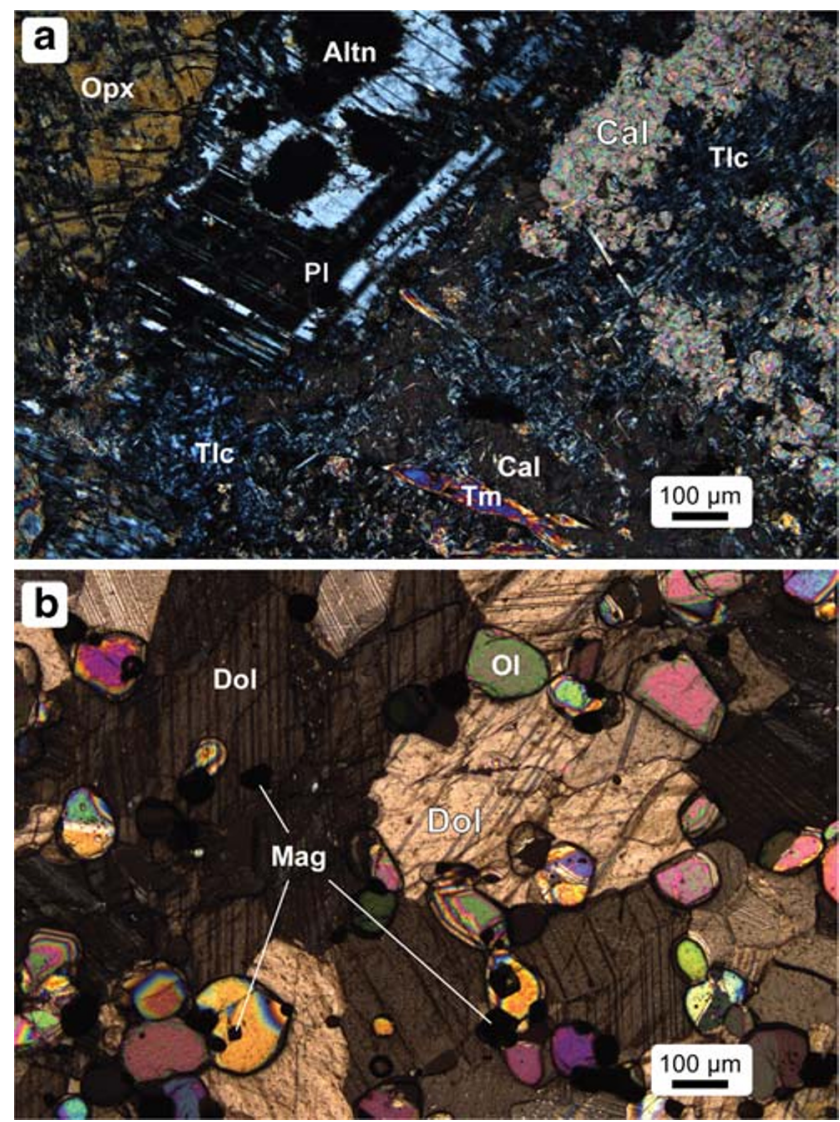

Fig. 1 Example of some of the carbonate-bearing lithologies in the drill core studied. a Small xenolith with optically continuous calcite relicts and patches of talc and tremolite within MU (sample UMT094-1285). Unaltered orthopyroxene and plagioclase grains show some alteration. Contacts between $\mathrm{Pl}$ and $\mathrm{Cal}$ are sharp where present. Altn, alteration, Cal, calcite, Opx, orthopyroxene, $\mathrm{Pl}$, plagioclase, Tlc, talc, Tm, tremolite. b Siliceous dolostone (sample UMT094-1601) with olivine and magnetite spread homogenously throughout. Olivine is interpreted to be the product of contact metamorphism. Dolomite shows some granoblastic recrystallization textures. Dol, dolomite, Mag, magnetite, Ol, olivine 


\section{Sulfide petrography}

Sulfide minerals are dominantly pyrrhotite, pentlandite, and chalcopyrite in the micro-drilled samples, with pyrite only observed in one of the samples analyzed by XRD. Within BU and MU, pyrrhotite and pentlandite occur interstitial to the silicate minerals whereas chalcopyrite tends to occur along grain boundaries of other sulfide minerals and associated with altered silicate minerals. Chalcopyrite and pyrite tend to be relatively more abundant in the deeper portions of the drill core. Pyrite is particularly abundant within and in the proximity of calc-silicate xenoliths.

\section{Whole rock geochemistry}

\section{Major elements}

Major element data are presented in ESM Table 2 and are summarized in Fig. 2. The variations in major element concentrations are largely controlled by modal variation in the proportion of plagioclase, clinopyroxene, and orthopyroxene. Some key trends in major element content include the following: (1) increases in $\mathrm{MgO}$ with increasing pyroxene content (Fig. 2a); (2) increases in $\mathrm{CaO}$ and $\mathrm{Al}_{2} \mathrm{O}_{3}$ contents with increasing plagioclase content and decreasing pyroxene content (Fig. $2 \mathrm{~b}$ and c); and (3) increases of $\mathrm{CaO}$ with depth, which is consistent with the appearance of xenoliths of dolomite or calc-silicate.

The plagioclase-rich Main Zone and plagioclase-rich sections of other units have $\mathrm{CaO} / \mathrm{Al}_{2} \mathrm{O}_{3}$ values averaging 0.6, whereas pyroxenite and feldspathic pyroxenite of the MU have values that are closer to 1.0 (Fig. 2d). At the base of the MU, between 1285 and $1292 \mathrm{~m}$, the $\mathrm{CaO} / \mathrm{Al}_{2} \mathrm{O}_{3}$ values increase to an average of 2.8 (Fig. 2d) possibly due to the presence of calcite and clinopyroxene. Within the FU, a calc-silicate xenolith is observed in thin section from sample UMT0941333 , which is spatially related to an increased $\mathrm{CaO} /$ $\mathrm{Al}_{2} \mathrm{O}_{3}$ value of 2.6. Within the $\mathrm{FAZ}, \mathrm{CaO} / \mathrm{Al}_{2} \mathrm{O}_{3}$ values are as high as 1.8 and become more variable towards the calc-silicate footwall. Within the calc-silicate footwall, $\mathrm{CaO} / \mathrm{Al}_{2} \mathrm{O}_{3}$ values are highly variable (between 0.49 and 12.0). Four samples from the dolostone footwall, collected from depths of between 1494 and $1601 \mathrm{~m}$ (end of hole), have an average $\mathrm{CaO} / \mathrm{Al}_{2} \mathrm{O}_{3}$ value of 15.8 and a maximum value of 19.0.

Total $\mathrm{S}$ values range from < detection limit $(0.01 \mathrm{wt} . \%)$ to a maximum of $1.5 \mathrm{wt} . \% \mathrm{~S}$ in the lower portion of UMT094 (Fig. 2e). In the MZ, sulfur contents are mostly below the detection limit (Fig. 2e). The $\mathrm{S} / \mathrm{Se}$ value (Fig. 2f) shows little variation in samples from FU, MU, and BU and, with few exceptions, are in the range of Merensky Reef samples from the western BIC and near mantle values, whereas samples from the UG2U, FAZ, calc-silicate, and footwall dolostone have much higher S/Se values (Fig. 2f). Sulfate (anhydrite) was only observed in two samples.

Loss on ignition (LOI) values are generally < 1 wt.\% within least-altered, magmatic sections of the drill core (Fig. 3a). Magmatic units with visible alteration or clay-rich bands show higher LOI values (up to 2 to 5 wt.\%), including within the MU (1279 to $1292 \mathrm{~m}$ ), with one sample at the base of the MU reaching $\mathrm{LOI}=5.66$ wt.\% (UMT094-1291A; Fig. 3a). Above $\sim 1350 \mathrm{~m}$, most samples, including UMT094$1291 \mathrm{~A}$, have $\mathrm{CaO} / \mathrm{LOI}>\sim 4$, consistent with little or no addition of carbonate during alteration. Conversely, most samples located deeper than $1350 \mathrm{~m}$ have $\mathrm{CaO} / \mathrm{LOI} \leq \sim 1$, consistent with addition of $\mathrm{Mg}$-rich carbonate by alteration or modification of footwall dolostone. Below the FU and through the FAZ, the LOI values increase progressively with depth (from $\sim 2 \mathrm{wt} . \%$ at $1334 \mathrm{~m}$ to $9 \mathrm{wt} . \%$ at $1405 \mathrm{~m}$; Fig. 3a) correlating with the increase in $\mathrm{CaO} / \mathrm{Al}_{2} \mathrm{O}_{3}$ values (Fig. 3c); the LOI values increase from 9 up to $30 \mathrm{wt} . \%$ (average $=16.9 \mathrm{wt}$. \%) within the calc-silicate and dolostone footwall (Fig. 3a).

\section{Lithophile trace elements}

Sulfur/selenium values were analyzed to constrain assimilation of crustal material (Fig. 2e, f). Samples with $\mathrm{S}$ concentrations less than $0.01 \%$ detection limit and Se concentrations less than the detection limit of $0.2 \mathrm{ppm}$ have been excluded from the $\mathrm{S} / \mathrm{Se}$ interpretation following methods of Barnes et al. (2009). Within the $\mathrm{BU}$ and $\mathrm{MU}$ (1230 to $1292 \mathrm{~m}$ ), S/Se values range between 1344 and 3400. Within the FU and UG2U (1292 to $1338 \mathrm{~m})$, S concentrations show local decreases (to the lower detection limit of $0.01 \mathrm{wt} \%$; Fig. 2e), and $\mathrm{S} / \mathrm{Se}$ values increase to 2578 to 4500 . The calc-silicate xenolith within the FU (1333.3 to $1333.6 \mathrm{~m}$ ) has a $\mathrm{S} / \mathrm{Se}$ value of 6050 , distinct from values of 3444 to 3750 within the UG2U. Below the $\mathrm{UG} 2 \mathrm{U}, \mathrm{S} / \mathrm{Se}$ values increase and become more variable (Fig. 2f). Within the FAZ and the Transval Supergroup footwall rocks (1338 to 1601), the average $\mathrm{S} / \mathrm{Se}$ value is 10,766 , but there is a wide range, between 3000 and 24,833 (Fig. 2f).

Whole rock trace element data from drill core UMT094 are summarized in ESM Tables 3 and 4. Data from drill cores ATS139 and UMT365, showing more metasedimentary contamination than UMT094, are summarized in ESM Table 5. The data from ATS139 

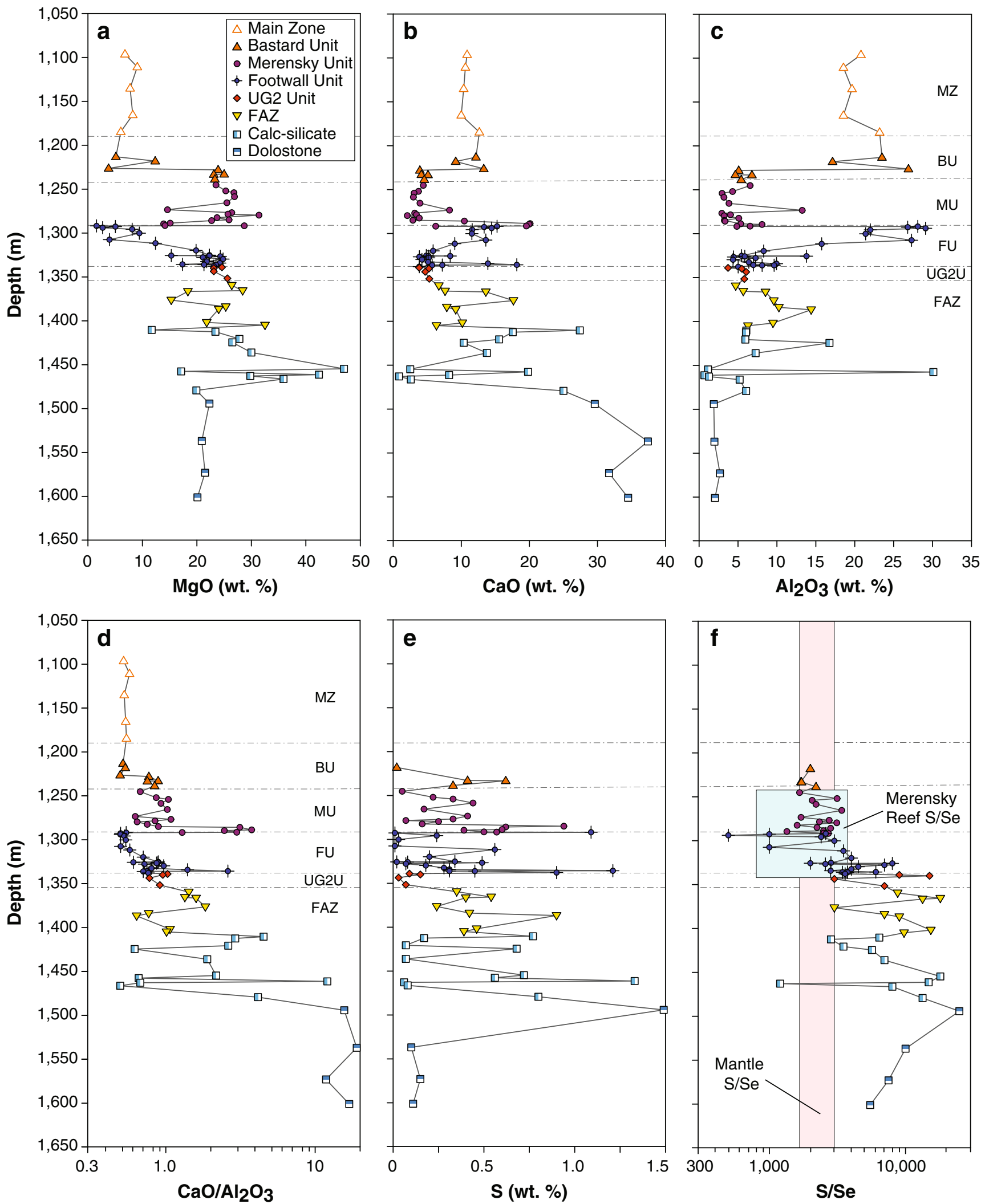

Fig. 2 Variations in selected whole rock elements with stratigraphy. a $\mathrm{MgO}, \mathbf{b ~ C a O}, \mathbf{c ~} \mathrm{Al}_{2} \mathrm{O}_{3}, \mathbf{d ~ C a O} / \mathrm{Al}_{2} \mathrm{O}_{3}$, e Total $\mathrm{S}$, and $\mathbf{f} \mathrm{S} / \mathrm{Se}$ variations with depth compared to Earth's primitive mantle and Merensky Reef reference

Reef values from eastern and western limbs from Barnes et al. (2009). Note that the MU shows S/Se values that are consistent with Merensky Reef, in contrast to the higher $\mathrm{S} / \mathrm{Se}$ in the underlying rocks 

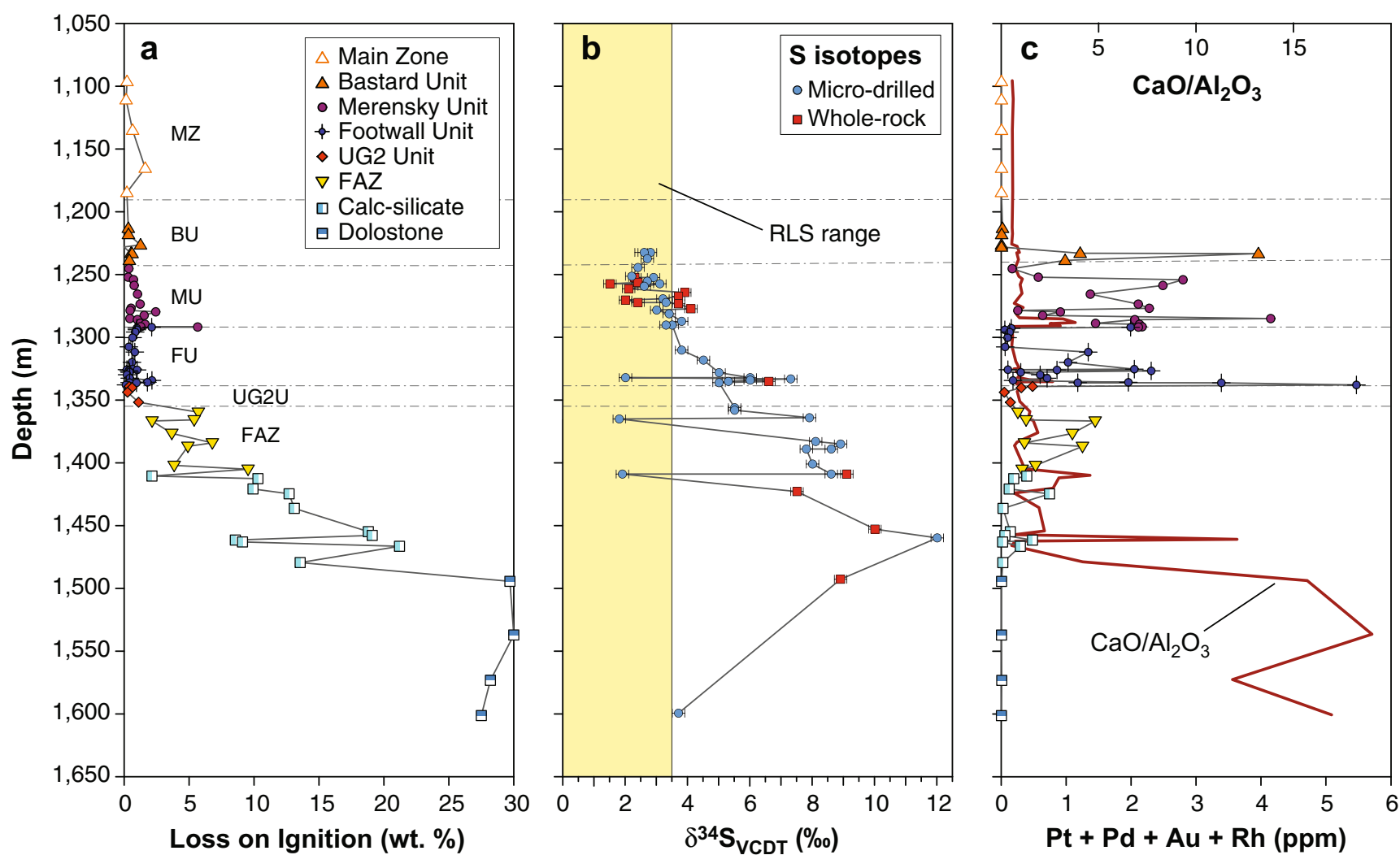

Fig. 3 Variations in a loss on ignition (LOI); $\mathbf{b} \delta^{34} \mathrm{~S} ; \mathbf{c ~ C a} / \mathrm{Al}_{2} \mathrm{O}_{3}$ and PGE with depth. The field in pale yellow represents the range in $\delta^{34} \mathrm{~S}$ (up to + $3.5 \%$ ) for the Rustenburg Layered Suite (Magalhães et al. 2018) not accounting for $2 \sigma$ uncertainties (which would expand the range to $4 \%$ )

and UMT365 are included in some geochemical interpretations to constrain the extent of (meta) shale contamination. The primary elements used in these interpretations to discern between magmatic contributions and sedimentary contributions are vanadium, titanium, nickel, chromium, and selenium.

The FAZ has V/Ti values ranging between 0.2 and 3, plotting both above and below those of the magmatic units. The calc-silicate footwall (1405 to $1494 \mathrm{~m}$ ) contains $\mathrm{V} / \mathrm{Ti}$ values as low as 0.054 , due to very low $\mathrm{V}$ contents (as low as $0.36 \%$ of primitive mantle values). Samples within a second analyzed drill hole, ATS139, which is in the up-dip section of the Platreef, contain substantial hornfelsed shale proximal to the MU and have $\mathrm{V} / \mathrm{Ti}$ values that are generally $>3.0$ within both its mineralized and contaminated units.

\section{Chalcophile elements}

Gold, Pt, Pd, and Rh data (from 1-m-long core samples) were provided by Ivanplats (ESM Table 6). Additional PGE and Au content data generated for this study are summarized in ESM Table 7. PGE and gold contents are close to, or below, detection limits through both the Main Zone (1096 to $1230 \mathrm{~m}$ ) and the dolostone xenolith at the base of drill hole UMT094 (1494 to $1601 \mathrm{~m}$; Fig. $3 \mathrm{c}$ ). Within the mineralized zones, these metals are enriched, i.e., BU (1230 to $1239 \mathrm{~m}$ : average $\sim 2000 \mathrm{ppb}$ $\mathrm{Pt}+\mathrm{Pd}+\mathrm{Au}+\mathrm{Rh}), \mathrm{MU}(1252$ to $1292 \mathrm{~m}$ : average $3600 \mathrm{ppb} \mathrm{Pt}+\mathrm{Pd}+\mathrm{Au}+\mathrm{Rh}$ ), and UG2U (1335 to $1338 \mathrm{~m}$ : average $\sim 4400 \mathrm{ppb} \mathrm{Pt}+\mathrm{Pd}+\mathrm{Au}+\mathrm{Rh})$. In the units between and below these mineralized intervals, i.e., within FU and FAZ, PGE and Au are much less abundant but are still elevated relative to the unmineralized $\mathrm{MZ}$ and sedimentary footwall (1239 to $1252 \mathrm{~m}, 1292$ to $1335 \mathrm{~m}$, and 1338 to $1405 \mathrm{~m}$ : average $\sim 600 \mathrm{ppb} \mathrm{Pt}+\mathrm{Pd}+\mathrm{Au}+\mathrm{Rh}$ ) (Fig. 3c).

\section{Sulfur isotopic data}

Whole rock and micro-drilled sulfur isotope values from drill core UMT094 (ESM Table 8; Fig. 3b) $\delta^{34} \mathrm{~S}$ values range between 1.5 and $12.0 \%$, with lower values higher up in the stratigraphy (1233 to $1282 \mathrm{~m}$, average = $2.6 \%$ ). Values increase with depth towards a maximum value $(1333$ and $1335 \mathrm{~m}, 7.5 \%$ ) above the FAZ. No sulfides were observed in the Main Zone. Three micro-drilled samples within the BU, dominated by pyrrhotite, yielded $\delta^{34} \mathrm{~S}$ values between 2.4 and $2.8 \%$. The range of $\delta^{34} \mathrm{~S}$ values of whole rock powders within the MU ranges between 1.5 and 3.8\%o (Fig. 3b). Sulfur 
isotope values increase through the FAZ (up to $8.1 \%$ ). In calc-silicate footwall rocks below the FAZ, $\delta^{34} \mathrm{~S}$ values (whole rock and micro-drilled; Fig. 3b) range between 7.5 and $12.0 \%$, for rocks with 0.1 to 0.7 wt.\% S (Fig. 2e). Only one sample of olivinebearing dolostone (Fig. 1b) contained sufficient sulfur (as pyrite) to be analyzed by micro-drilling. The $\delta^{34} \mathrm{~S}$ value for this sample was $3.7 \%$, much lower compared to the nearest calc-silicate which showed a $\delta^{34} \mathrm{~S}$ value of $8.9 \%$ (Fig. 3b).

\section{Discussion}

There has been some debate in the literature as to whether or not the Platreef represents the lateral equivalent of the Upper Critical Zone of the eastern and western limbs of the BIC (Langa et al. 2020; Grobler et al. 2019; Kinnaird 2005; Sharman et al. 2013; Mayer et al. 2020; Maier et al. 2020). Much of this debate has centered around differing interpretations regarding the extent of crustal assimilation in the Platreef magmas, in particular the role of the addition of crustal $\mathrm{S}$ to generate the atypical thickness of PGE mineralization in the Platreef compared to the rest of the BIC (Holwell et al. 2007; Sharman et al. 2013).

One of the main contaminants in the section are footwall marbles (dolostone, primarily). Thus, $\mathrm{CaO} /$ $\mathrm{Al}_{2} \mathrm{O}_{3}$ is a useful parameter to track carbonate assimilation, as assimilation of dolostone would produce an increase in $\mathrm{CaO}$ but not in $\mathrm{Al}_{2} \mathrm{O}_{3}$. Similarly, other geochemical parameters, such as loss on ignition and $\delta^{34} \mathrm{~S}$ help track variations in local footwall assimilation within UMT094 relative to variations in PGE and Au contents (Fig. 3).

Within the studied drill core, there are several intervals characterized by geochemical evidence for increased contamination: (i) between 1285 and $1292 \mathrm{~m}$, i.e., within $\mathrm{MU}$, the $\mathrm{Ca} / \mathrm{Al}_{2} \mathrm{O}_{3}$ value increases from $\sim 1$ to $\sim 2.6$. The upper and lower bounds of this excursion are marked by sharp shifts. Increases in LOI (up to 5.66 wt.\% at $1291 \mathrm{~m}$ ) and decreases in PGE contents coincide with this band, along with a minor change in $\delta^{34} \mathrm{~S}$ (from 1282 to $1288 \mathrm{~m}=3.4$ to $3.8 \%$ ). (ii) Within the $\mathrm{FU}$, there is a large increase in $\delta^{34} \mathrm{~S}$ (to $7.5 \%$ ) at $1333 \mathrm{~m}$, with a minor increase in LOI and some significant variations in PGE content. Small calc-silicate xenoliths were identified in this segment. (iii) Within the FAZ, from $1352 \mathrm{~m}$ until the end of the drill core, samples reach LOI up to $30 \mathrm{wt} . \%, \delta^{34} \mathrm{~S}$ values increase to up to $12 \%$, values of $\mathrm{CaO} / \mathrm{Al}_{2} \mathrm{O}_{3}$ are above 15 , and $\mathrm{PGE}$ tenor contents are as low as $6 \mathrm{ppb}$ (ESM
Table 7). In contrast, the MZ, BU, most of the MU and the FU, and parts of the UG2U do not show increases in $\mathrm{CaO} / \mathrm{Al}_{2} \mathrm{O}_{3}$, LOI, or $\delta^{34} \mathrm{~S}$. This is interpreted as evidence of minimal contamination by local footwall lithologies.

Figure 4 compares two element ratios, normalized to primitive mantle values (PM), which are useful to distinguish magmatic units from those that show contamination with different types of sedimentary footwall. Magmatic samples have $[\mathrm{V} / \mathrm{Ti}]_{\mathrm{PM}}$ ranging between 1 and 2, dolostone and calc-silicate samples have $[\mathrm{V} / \mathrm{Ti}]_{\mathrm{PM}}<1$, and hornfelsed shales have $[\mathrm{V} / \mathrm{Ti}]_{\mathrm{PM}}>2$, making $[\mathrm{V} / \mathrm{Ti}]_{\mathrm{PM}}$ a useful parameter to distinguish magmatic samples from specific local country rocks in UMT094. Several samples within the FAZ have $[\mathrm{V} / \mathrm{Ti}]_{\mathrm{PM}}$ values below unity. Some MU and FAZ samples located proximal to Transvaal Supergroup shales within drill core ATS139 have $[\mathrm{V} / \mathrm{Ti}]_{\mathrm{PM}}$ up to $>2$, within the field defined by hornfelsed shale samples. Nickel and chromium ratios are also used to compare magmatic samples to sedimentary samples and to distinguish between the various units of the BIC. Chromium contents are the highest within chromitebearing units, notably within the UG2U. Chromium

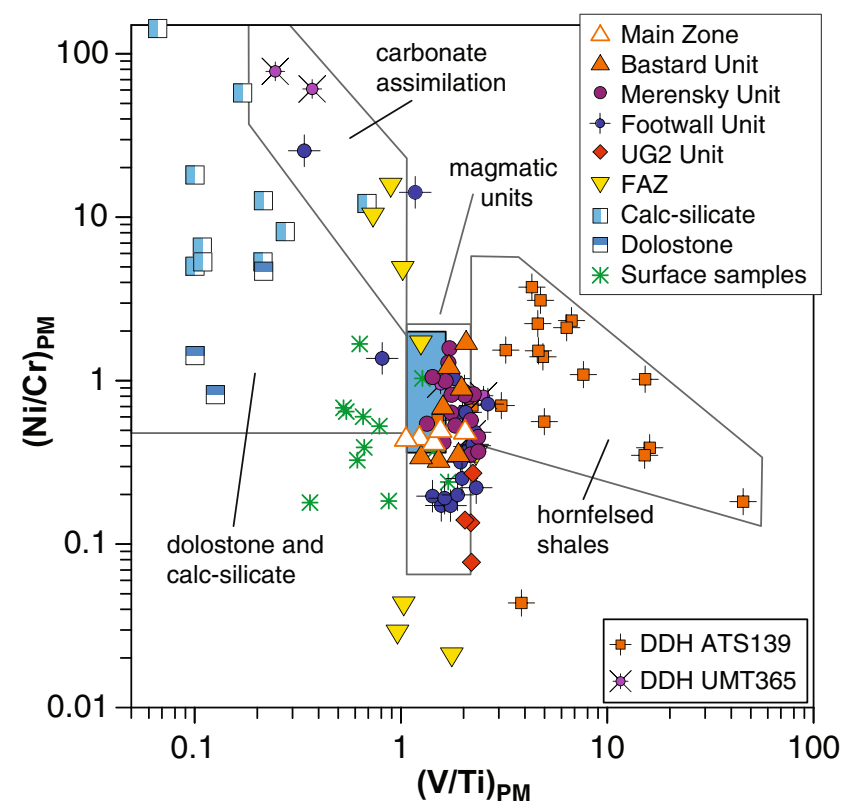

Fig. 4 Primitive-mantle normalized plot of $\mathrm{Ni} / \mathrm{Cr}$ against $\mathrm{V} / \mathrm{Ti}$ showing field of magmatic rocks and footwall lithologies. Variations in V/Ti are useful to distinguish the two main contaminants present from the magmatic units. Calc-silicate shifts V/Ti to less than 1 whereas assimilation of shales shifts $\mathrm{V} / \mathrm{Ti}$ to more than 2 . The $\mathrm{Ni} / \mathrm{Cr}$ values are mostly a reflection of the relative proportion of Ni-bearing minerals (pentlandite, olivine, pyroxene) to chromite (e.g., samples containing chromitite seams within the UG2U and FAZ show the lowest $\mathrm{Ni} / \mathrm{Cr}$ values). Primitive mantle values are from McDonough and Sun (1995) 

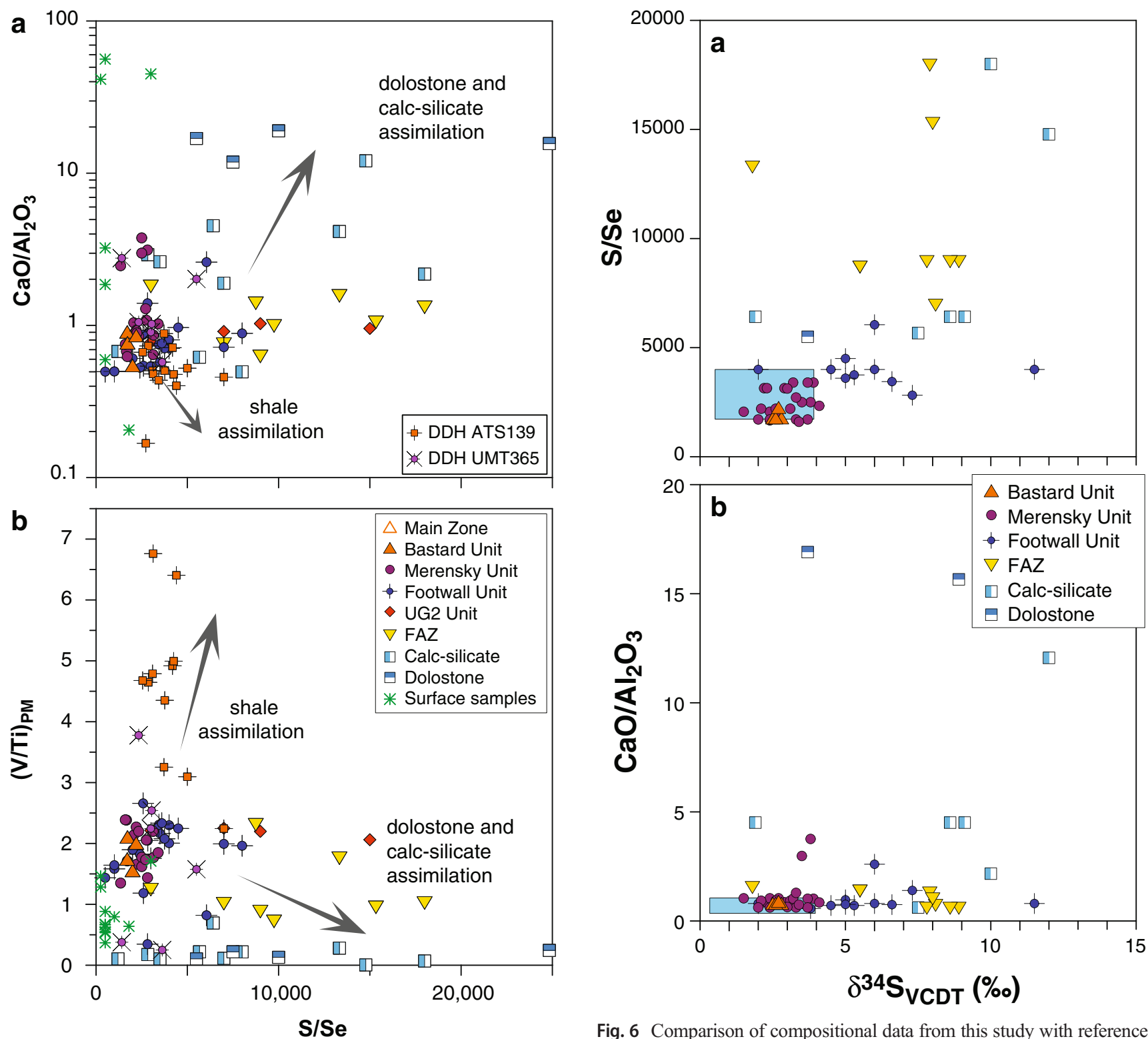

Fig. 5 Ratio plots vs $\mathrm{S} / \mathrm{Se}$ of $\mathbf{a} \mathrm{CaO} / \mathrm{Al}_{2} \mathrm{O}_{3}$ and $\mathbf{b} \mathrm{V} / \mathrm{Ti}$. Assimilation of dolostone increases both $\mathrm{S} / \mathrm{Se}$ and $\mathrm{CaO} / \mathrm{Al}_{2} \mathrm{O}_{3}$. Assimilation of shales causes a small decrease in $\mathrm{CaO} / \mathrm{Al}_{2} \mathrm{O}_{3}$. Some $\mathrm{MU}$ samples appear to have assimilated carbonate (increased $\mathrm{Ca} / \mathrm{Al}_{2} \mathrm{O}_{3}$ ) without an increase in $\mathrm{S} / \mathrm{Se}$, which indicates no significant addition of crustal S. In b, assimilation of shales increases V/Ti with a slight increase in $\mathrm{S} / \mathrm{Se}$ values. Assimilation of dolostone increases $\mathrm{S} / \mathrm{Se}$ and decreases V/Ti. Shale data are from drill cores ATS139 and UMT365 due to the scarcity of shales in UMT094

Fig. 6 Comparison of compositional data from this study with reference values (blue fields) for Merensky Unit in the eastern and western limbs ( $\mathrm{S} / \mathrm{Se}$ from Barnes et al. (2009); $\mathrm{CaO} / \mathrm{Al}_{2} \mathrm{O}_{3}$ from Wilson and Chunnett (2006); $\delta^{34} \mathrm{~S}$ from Penniston-Dorland et al. 2012). a S/Se vs. $\delta^{34} \mathrm{~S}$, showing very good match between $\mathrm{MU}$ in the eastern and western limbs and the samples from the MU analyzed in the present study. $\mathbf{b ~ C a O} / \mathrm{Al}_{2} \mathrm{O}_{3}$ vs. $\delta^{34} \mathrm{~S}$ showing good match between the MU at Turfspruit and the reference values, except for local contamination in a few samples, which resulted in an increase in $\mathrm{CaO} / \mathrm{Al}_{2} \mathrm{O}_{3}$, but insignificant changes in $\mathrm{S} / \mathrm{Se}$ vs. $\delta^{34} \mathrm{~S}$. The systematic increase in $\mathrm{CaO} / \mathrm{Al}_{2} \mathrm{O}_{3}, \mathrm{~S} / \mathrm{Se}$, and $\delta^{34} \mathrm{~S}$ trends for the FU and the FAZ reflect increasing degrees of local footwall assimilation 
contents are moderate within units containing chromite stringers (FU, MU) and extremely low (commonly near zero) within footwall units. Nickel contents are controlled by pentlandite and olivine content. Data from Yudovskaya et al. (2018) show similar trends for anhydrite-bearing metasedimentary rafts intersected between the FAZ and the Lower Zone. The V/Ti values of the metasedimentary raft (between 0.17 and 0.21 ) are below magmatic values, whereas values from the Lower Zone (between 1.09 and 1.34) are within the range for magmatic units.

Based on the $\mathrm{Ca} / \mathrm{Al}$ and $\mathrm{S} / \mathrm{Se}$ plots versus height (Fig. 2d, e), the contaminated signature within the FAZ in UMT094 extends upwards from the lower contact of the unit with dolostone footwall through more than $50 \mathrm{~m}$ of the FAZ, including parts of the UG2U. The $\delta^{34} \mathrm{~S}$ values show some degree of contamination through the FU but approach the values for the Merensky Unit in the eastern and western limbs. Within the MU and $\mathrm{BU}$, the $\delta^{34} \mathrm{~S}$ values range between +1.5 and $+4 \%$ o (Fig. $3 b$ ), only slightly above the range previously documented for the UCZ in the eastern limb (Magalhães et al. 2018) and similar to what Holwell et al. (2007) considered to be primary sulfide minerals $\left(\delta^{34} \mathrm{~S} \leq+2.6 \%\right)$ in samples from the Sandsloot, Zwartfontein, Overysel, and Witrivier portions of the Platreef.

Sharman et al. (2013) suggested that the large range in $\Delta^{33} \mathrm{~S}$ and $\delta^{34} \mathrm{~S}$ of Platreef rocks indicated that the Platreef magmas were contaminated prior to the emplacement of the Platreef magmas. We have shown here with the $\delta^{34} \mathrm{~S}, \mathrm{~S} / \mathrm{Se}, \mathrm{CaO} / \mathrm{Al}_{2} \mathrm{O}_{3}$, and $\mathrm{Ti} / \mathrm{V}$ values (Figs. 2, 3, and 4) and elsewhere with $\mathrm{Sr}$ isotopic values (Mayer et al. 2020) that UMT094 intersected Upper Critical Zone magmatic rocks and associated PGE mineralization at the stratigraphic position of the Merensky Reef in which there is little to no evidence for proximal assimilation as shown by $\delta^{34} \mathrm{~S}$ and ${ }^{87} \mathrm{Sr}^{86}{ }^{8 \mathrm{Sr}_{i}}$ values similar to those of the eastern and western limbs of the BIC). Conversely, the lower part of the Platreef stratigraphy in UMT094, which includes the stratigraphic equivalent of the UG2, shows evidence for local assimilation in $8^{34} \mathrm{~S}, \mathrm{~S} / \mathrm{Se}, \mathrm{CaO} / \mathrm{Al}_{2} \mathrm{O}_{3}$, and $\mathrm{Ti} /$ V (Figs. 2, 3, 4, 5, and 6). Our data do not obviate the need for contamination prior to emplacement of the Platreef; the $\delta^{34} \mathrm{~S}$ and ${ }^{87} \mathrm{Sr}^{86} \mathrm{Sr}_{i}$ values broadly overlap or are only very slightly higher than those of the eastern and western limbs of the BIC, but as shown by Penniston-Dorland et al. (2012), the slightly positive
$\Delta^{33} \mathrm{~S}$ values of the Merensky Reef in the eastern and western limbs indicate that small amounts of external $\mathrm{S}$ was incorporated into the BIC melts prior to emplacement of the Merensky Reef.

\section{Conclusions}

The combined data obtained for drill core UMT094 (whole rock major and trace element chemistry, and $\delta^{34} \mathrm{~S}$ ) suggest that the extent of assimilation of Transvaal metasedimentary rocks is largely limited to intervals located below the main PGE reefs. The combination of $\mathrm{CaO} / \mathrm{Al}_{2} \mathrm{O}_{3}, \mathrm{~V} / \mathrm{Ti}, \mathrm{S} / \mathrm{Se}, \mathrm{LOI}$, and $\delta^{34} \mathrm{~S}$ show a gradual decreasing trend of local assimilation from the Footwall Assimilation Zone to the Footwall Unit below the Merensky Unit. The overall trend is interrupted by local anomalies caused mainly by dolostone and calcite xenoliths, including some at the base of the MU; however, the PGE mineralization in the MU is clearly contained within relatively weakly contaminated magmatic units. The values of $\delta^{34} \mathrm{~S}$ obtained in the mineralized interval of UMT094 are consistent with $\delta^{34} \mathrm{~S}$ values from the Merensky Reef in the eastern and western limbs of the Bushveld where no local contamination is documented. The results summarized here thus indicate that the primary mechanism of PGE mineralization in the Platreef at Turfspruit is no different than the mechanisms that operated in the rest of the BIC.

Acknowledgments We thank the technical team at QFIR for assistance with the S isotope, SEM, and XRD analyses, in particular Evelyn Leduc, Agatha Dobosz, Dylan Layton-Matthews, and April Vuletich. The staff at Ivanplats in Mokopane are thanked for their outstanding work in organizing the core facilities and making sampling in the South African heat a pleasure. We also wish to extend our thanks and appreciation to journal editor-in-chief Georges Beaudoin, Guest Editor Wolfgang Maier, and the two reviewers Chris Harris and Chusi $\mathrm{Li}$ for their thoughtful and constructive comments on the manuscript, which helped to greatly improve the paper.

Funding Funding for this research was provided by the Queen Elizabeth II Diamond Jubilee Scholarship program and a Collaborative Research and Development partnership between Ivanplats and the Natural Sciences and Engineering Research Council of Canada (NSERC; funding reference number CRDPJ 514753-17). 
Open Access This article is licensed under a Creative Commons Attribution 4.0 International License, which permits use, sharing, adaptation, distribution and reproduction in any medium or format, as long as you give appropriate credit to the original author(s) and the source, provide a link to the Creative Commons licence, and indicate if changes were made. The images or other third party material in this article are included in the article's Creative Commons licence, unless indicated otherwise in a credit line to the material. If material is not included in the article's Creative Commons licence and your intended use is not permitted by statutory regulation or exceeds the permitted use, you will need to obtain permission directly from the copyright holder. To view a copy of this licence, visit http://creativecommons.org/licenses/by/4.0/.

\section{References}

Armitage PEB, McDonald I, Edwards SJ, Manby GM (2002) Platinum-group element mineralization in the Platreef and calc-silicate footwall at Sandsloot, Potgietersrus District, South Africa. Appl Earth Sci 111:36-45. https://doi.org/10. 1179/aes.2002.111.1.36

Barnes S-J, Savard D, Bédard LP, Maier WD (2009) Selenium and sulfur concentrations in the Bushveld Complex of South Africa and implications for formation of the platinum-group element deposits. Mineral Deposita 44:647-663. https://doi.org/10.1007/s00126009-0237-3

Barnes S-J, Maier WD, Curl EA (2010) Composition of the marginal rocks and sills of the Rustenburg Layered Suite, Bushveld Complex, South Africa: implications for the formation of the platinum-group element deposits. Econ Geol 105:1491-1511. https://doi.org/10.2113/econgeo.105.8.1491

Buchanan DL, Nolan J, Suddaby P, Rouse JE, Viljoen MJ, Davenport JWJ (1981) The genesis of sulfide mineralization in a portion of the Potgietersrus limb of the Bushveld Complex. Econ Geol 76:568579. https://doi.org/10.2113/gsecongeo.76.3.568

Cameron EN (1978) The lower zone of the eastern Bushveld Complex in the Olifants River trough. J Petrol 19:437-462. https://doi.org/10. 1093/petrology/19.3.437

Cawthorn RG, Eales HV, Walraven F, Uken R, Watkeys MK (2006) The Bushveld Complex. In: Johnson MR, Anhaeusse CR, Thomas RJ (eds) The geology of South Africa. Geological Society of South Africa, Johannesburg, pp 261-281

Engelbrecht JP (1990) The Marico hypabyssal suite, and the marginal zone of the Bushveld Complex in the Marico District, western Transvaal. South Africa South African Journal of Geology 93: 318-328

Eroglu S, Schoenberg R, Wille M, Beukes N, Taubald H (2015) Geochemical stratigraphy, sedimentology, and Mo isotope systematics of the ca. 2.58-2.50 Ga-old Transvaal Supergroup carbonate platform, South Africa. Precambrian Res 266:27-46. https://doi.org/ 10.1016/j.precamres.2015.04.014

Gain SB, Mostert AB (1982) The geological setting of the platinoid and base metal sulfide mineralization in the Platreef of the Bushveld Complex in Drenthe, north of Potgietersrus. Econ Geol 77:1395-1404. https://doi.org/10. 2113/gsecongeo.77.6.1395

Grobler DF, Brits JAN, Maier WD, Crossingham A (2019) Litho- and chemostratigraphy of the Flatreef PGE deposit, northern Bushveld
Complex. Mineral Deposita 54:3-28. https://doi.org/10.1007/ s00126-018-0800-x

Harris C, Chaumba JB (2001) Crustal contamination and fluid-rock interaction during the formation of the Platreef, northern limb of the Bushveld Complex, South Africa. J Petrol 42:1321-1347. https:// doi.org/10.1093/petrology/42.7.1321

Holwell DA, Boyce AJ, McDonald I (2007) Sulfur isotope variations within the Platreef Ni-Cu-PGE deposit: genetic implications for the origin of sulfide mineralization. Econ Geol 102:1091-1110. https://doi.org/10.2113/gsecongeo.102.6.1091

Kinnaird JA (2005) Geochemical evidence for multiphase emplacement in the southern Platreef. Appl Earth Sci 114:225-242. https://doi. org/10.1179/037174505x82152

Kruger FJ (2005) Filling the Bushveld Complex magma chamber: lateral expansion, roof and floor interaction, magmatic unconformities, and the formation of giant chromitite, PGE and Ti-V-magnetitite deposits. Mineral Deposita 40:451-472. https://doi.org/10.1007/ s00126-005-0016-8

Langa MM, Jugo PJ, Leybourne MI, Grobler DF, Adetunji J, Skogby H (2020) Chromite chemistry of a massive chromitite seam in the northern limb of the Bushveld Igneous Complex, South Africa: correlation with the UG-2 in the eastern and western limbs and evidence of variable assimilation of footwall rocks. Mineral Deposita. https://doi.org/10.1007/s00126-020-00964-y

Magalhães N, Penniston-Dorland S, Farquhar J, Mathez EA (2018) Variable sulfur isotope composition of sulfides provide evidence for multiple sources of contamination in the Rustenburg Layered Suite, Bushveld Complex. Earth Planet Sci Lett 492:163-173. https://doi.org/10.1016/j.epsl.2018.04.010

Maier WD, Barnes SJ, Groves DI (2013) The Bushveld Complex, South Africa: formation of platinum-palladium, chrome- and vanadiumrich layers via hydrodynamic sorting of a mobilized cumulate slurry in a large, relatively slowly cooling, subsiding magma chamber. Mineral Deposita 48:1-56. https://doi.org/10.1007/s00126-0120436-1

Maier WD, Yudovskaya M, Jugo PJ (2020) Introduction to the special issue on the Flatreef PGE-Ni-Cu deposit, northern limb of the Bushveld Igneous Complex. Mineral Deposita

Manyeruke T (2005) Major and trace element geochemistry of the Platreef on the farm Townlands, northern Bushveld Complex. South African Journal of Geology - S AFR J GEOL 108:381-396. https://doi.org/10.2113/108.3.381

Manyeruke TD, Maier WD, Barnes S-J (2005) Major and trace element geochemistry of the Platreef on the farm Townlands, northern Bushveld Complex. S Afr J Geol 108:381-396

Mayer CC, Jugo PJ, Leybourne MI, Grobler DF, Voinot A (2020) Strontium isotope stratigraphy through the Flatreef PGE-Ni$\mathrm{Cu}$ mineralization at Turfspruit, northern limb of the Bushveld Igneous Complex: evidence of correlation with the Merensky Unit of the eastern and western limbs. Mineralium Deposita. https://doi.org/10.1007/s00126-02001006-3

McDonald I, Holwell DA, Li C, Ripley EM (2011) Geology of the northern Bushveld Complex and the setting and genesis of the Platreef Ni-Cu-PGE deposit magmatic Ni-Cu and PGE deposits: geology, geochemistry, and genesis. Society of Economic Geologists, pp 0

McDonough WF, Sun SS (1995) The composition of the Earth. In: McDonough WF, Arndt NT, Shirey S (eds) Chemical evolution of the mantle. Elsevier, Amsterdam, pp 223-253 
Mudd GM (2012) Key trends in the resource sustainability of platinum group elements. Ore Geol Rev 46:106-117. https://doi.org/10.1016/ j.oregeorev.2012.02.005

Naldrett AJ, Wilson A, Kinnaird J, Chunnett G (2009) PGE tenor and metal ratios within and below the Merensky Reef, Bushveld Complex: implications for its genesis. J Petrol 50:625-659. https:// doi.org/10.1093/petrology/egp015

Penniston-Dorland SC, Mathez EA, Wing BA, Farquhar J, Kinnaird JA (2012) Multiple sulfur isotope evidence for surface-derived sulfur in the Bushveld Complex. Earth Planet Sci Lett 337-338:236-242. https://doi.org/10.1016/j.epsl.2012.05.013

Sharman ER, Penniston-Dorland SC, Kinnaird JA, Nex PAM, Brown M, Wing BA (2013) Primary origin of marginal Ni-Cu-(PGE) mineralization in layered intrusions: $\triangle 33 \mathrm{~S}$ evidence from the Platreef, Bushveld, South Africa. Econ Geol 108:365-377. https://doi.org/ 10.2113/econgeo.108.2.365

Sharman-Harris ER, Kinnaird JA, Harris C, Horstmann UE (2005) A new look at sulphide mineralisation of the northern limb, Bushveld Complex: a stable isotope study. Appl Earth Sci 114:252-263. https://doi.org/10.1179/037174505X82134

Wagner PE (1929) The platinum deposits and mines of South Africa. Oliver and Boyd, London
Wilson AH, Chunnett G (2006) Trace Element and Platinum Group Element Distributions and the Genesis of the Merensky Reef, Western Bushveld Complex, South Africa. J Petrol 47:2369-2403

Yudovskaya MA, Kinnaird JA, Sobolev AV, Kuzmin DV, McDonald I, Wilson AH (2013) Petrogenesis of the lower zone olivine-rich cumulates beneath the Platreef and their correlation with recognized occurrences in the Bushveld Complex*. Econ Geol 108:1923-1952. https://doi.org/10.2113/econgeo.108.8. 1923

Yudovskaya MA, Sluzhenikin SF, Costin G, Shatagin KN, Dubinina EO, Grobler DF, Ueckermann H, Kinnaird JA (2018) Anhydrite assimilation by ultramafic melts of the Bushveld Complex, and its consequences to petrology and mineralization. In: Arribas AM, Mauk JL (eds) Metals, minerals, and society. Society of Economic Geologists, Kansas, pp 177-206

Publisher's note Springer Nature remains neutral with regard to jurisdictional claims in published maps and institutional affiliations. 